\title{
ANALYZING SITE SUITABILITY FOR SOLID WASTE DISPOSAL THROUGH GIS MULTI-CRITERIA DECISION MAKING HIERARCHY PROCESS
}

Sikandar Ali Shah

Department of Geography, University of Karachi, (Pakistan)

E-mail: sayed.sikandar24@gmail.com

Prof. Dr. Engr. Sayed Hyder Abbas Musvi

Indus University, Karachi, (Pakistan)

E-mail: dean@indus.edu.pk

Abeela Tameez

Department of Geography, University of Karachi, (Pakistan)

Masood Alam

Department of Geography, University of Karachi, (Pakistan)

Asim Nawaz

Department of Geography, University of Karachi, (Pakistan) 


\section{ABSTRACT}

Currently the human beings are encircled by multiple types of problems, out of those the environmental degradation issue is one of the major problem which is caused by over population, rapid increase of urbanization and industrialization which result in production of huge quantity of solid wastes. Thus the effectual solid waste management and its disposal arrangements are required. Another major problem being faced globally is to locate an appropriate area for the disposal of hazardous wastes by overcoming main constraints including environmental, economic and political for spotting of a suitable site. In this study our focus is to spot a proper landfill site for the disposal of hazardous wastes for which we have selected industrial (radioactive) wastes of the district of Karachi East as a area for research. This district has wide range of Korangi Industrial Area and small portion of Landhi Industrial Area. In this research we have used methods of Decision Support System (DSS) based on Geographical Information System (GIS) and Remote Sensing (RS) concerning all supportable measures. With the assist of Analytic Hierarchy Process (AHP) and Multi-Criteria Decision Making (MCDM), suitable alternative site for dumping solid waste has been selected on the basis of different factors performed on Arc Map 10.3, Erdas Imagine, e-Cognition developer by considering the decision maker's expectations. The results show that after performing different investigations on the suitability indexes, the analyzed area which is most suitable for solid waste dumping is $200 \mathrm{~m}$ away from Malir River.

\section{KEYWORDS}

Decision support system (DSS), landfill site, hazardous wastes, Multi-Criteria Decision Making (MCDM), Spatial Decision Support System (SDSS), Analysis Hierarchy Process (AHP).

\section{INTRODUCTION}

Solid Waste (SW) material contains all kinds of surplus such as trash, waste, sludge and few more solid garbage that are produced from human and other living thing's activities which is usually rejected to reuse or recycle including industrial, agricultural, commercial and society activities excluding sewage material from residential area, silt in water, poised solids in wastewater sewage from industries, suspended particles in irrigation system and other multiple common types of water pollutants. From the Document Driven Decision Support System's perspective which is applied in this study, Solid Waste Management (SWM) is one of the most important services which are getting extensive attention in the urban agenda of several developing countries [1]. Due to less concentration of SWM, it has been observed that there are numerous environmental degradation vulnerabilities along with health risks. This problem becomes wider and reaches beyond the geographical margins of towns or cities. Generally the Solid waste management is a calamity in several major urban regions of the world, as populations are attracted toward cities which continue to increase urbanization leading to continuously increasing amount of residential solid waste; whereas space for disposal is limited. Similarly in many developing cities and towns, inapt managing and disposal of municipal solid waste is most conspicuous reason of environmental degradation [2], for example air, water, soil and land pollution etc, which is caused by inappropriate disposal of municipal solid wastes. Although in the early 1990s; about US\$25 billion is spent annually just on solid waste management by Asian countries this figure is estimated 
to increase approximately US $\$ 50$ billion by 2025[3]. Rapid Increase in population results in rising quantity of solid waste with higher rate and has remained a challenge for Pakistan also, however it has been examined that the spawned waste is carried out and either dumped in low lying areas or burned in open environment exclusive of analyzing the disposal hazards and spot. This study has been carried out to assess the possibility of landfill site selection for solid waste dumping (SWD). Presently, Pakistan is suffering from solid waste issue and has received lesser attention for an adequate and appropriate ways of collection, transportation, disposal and dumping due to the large sizes of its cities, consequently, the environmental and sanitary conditions are becoming critical with the passage of time, and thus public social life is continuously deteriorating [4]. According to survey report of 1998 out of 130.579 million population of Pakistan, 67\% is living in countryside areas, whereas $33 \%$ reside in cities. Moreover, out of $33 \%$ of people existing in cities, from which $54 \%$ exist in 10 main cities of Pakistan [5]. Throughout the past various decades, migration has begun from rural to urban regions. The main reasons which cause this migration are as less crop yields, slow growth in agricultural zones, unemployment and environmental damages because of deforestation, water scarcity and desertification. The huge countryside inundation has, sequentially added to the overload on urban infrastructure and services [6]. The at present approximately 6000 tons per day waste dumping is required in Karachi which is one of the largest city of Sindh province of Pakistan, but it has not been conducted in adequate and appropriate manners in collection, transportation and disposal, as a result, the sanitary and environmental circumstances have further worsened, as well as public is suffering from passing their lives in polluted situation. These exposure consist on expending rate of urban areas, structure and compactness of urban regions, planning and reign of progress, temperature and precipitation, scavenger's commotion for recyclable partition, ability sufficiency as well as the restrictions of several precincts to control the waste damage, collect, transport and dispose [7]. Karachi is a metropolitan city of Pakistan has inappropriate municipal solid waste management system as well. The existing solid waste collection and transportation management system in Karachi is not perfect. There is inadequacy for extensive term plans, consequently in some cases rambling, ad-hoc and often damaging plan, guidelines and organizational schemes exist. The municipal infrastructure construction has been lagged by the economic development, which become the bottle-neck to hinder the faster and better development of the municipal economy. Waste collection, disposal, transport and street sweeping, duty lies with the municipal authorities. It has created suggestion for improved container design and promotes consciousness of solid waste management [8].

\section{STUDY AREA}

Karachi East is a densely populated district of Karachi city and it has a large important and famous areas such as Jinnah International Airport, PAF Base Faisal, PAF Museum, Pakistan Maritime Museum, Karachi Universty, NED University, Sir Syed University of Engineering and Technology, Federal Urdu University Of Arts Science \& Technology, Bahria University, Safari Park, Aladin Amusement Park, Sindhbad Play Land, Liaquat National Hospital, Agha Khan Hospital, Korangi Industrial Area and some part of Landhi Industrial Area; all covering an area of 
$140 \mathrm{~km} 2$. It is located at $24^{\circ} 45^{\prime \prime}$ to $25^{\circ} 15^{\prime \prime}$ north and $66^{\circ} 37^{\prime \prime}$ to $67^{\circ} 37^{\prime}$ east. It has Malir District in the north-east, Karachi West District in the North-West, Karachi South District in the south and Karachi Central District to the west as shown in Fig.1 and located near to the coast resulting relatively mild climate.

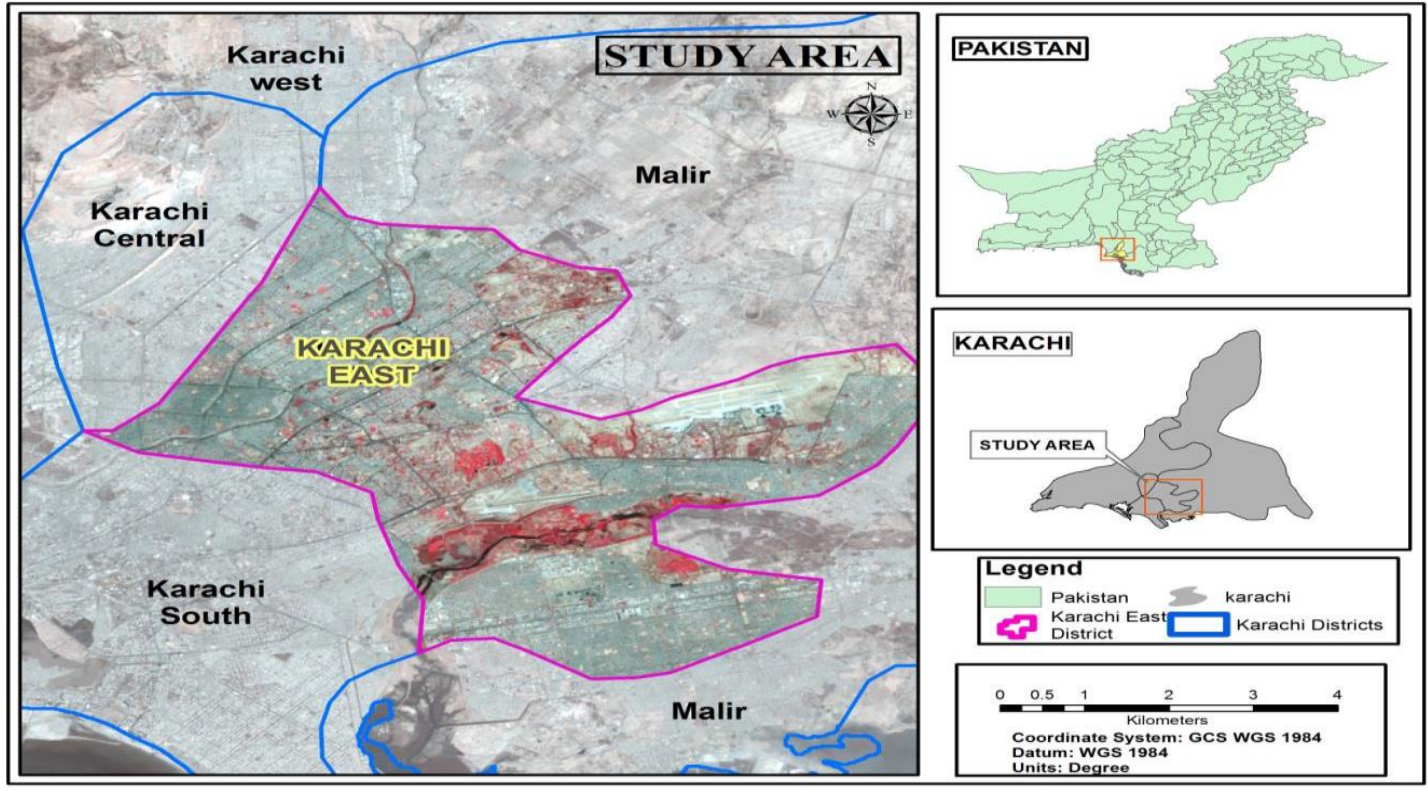

Figure 1. Location of Karachi East Pakistan.

The district of Karachi East has been shifted through knowledge driven Decision Support System which is analyzed by (SWOT) (planning method/tool) shown in Figure 2 and its outreach described in suitability analysis [9]. Therefore, our purpose is to use the technique of SWOT planning expeditious in life cycle of OBIA

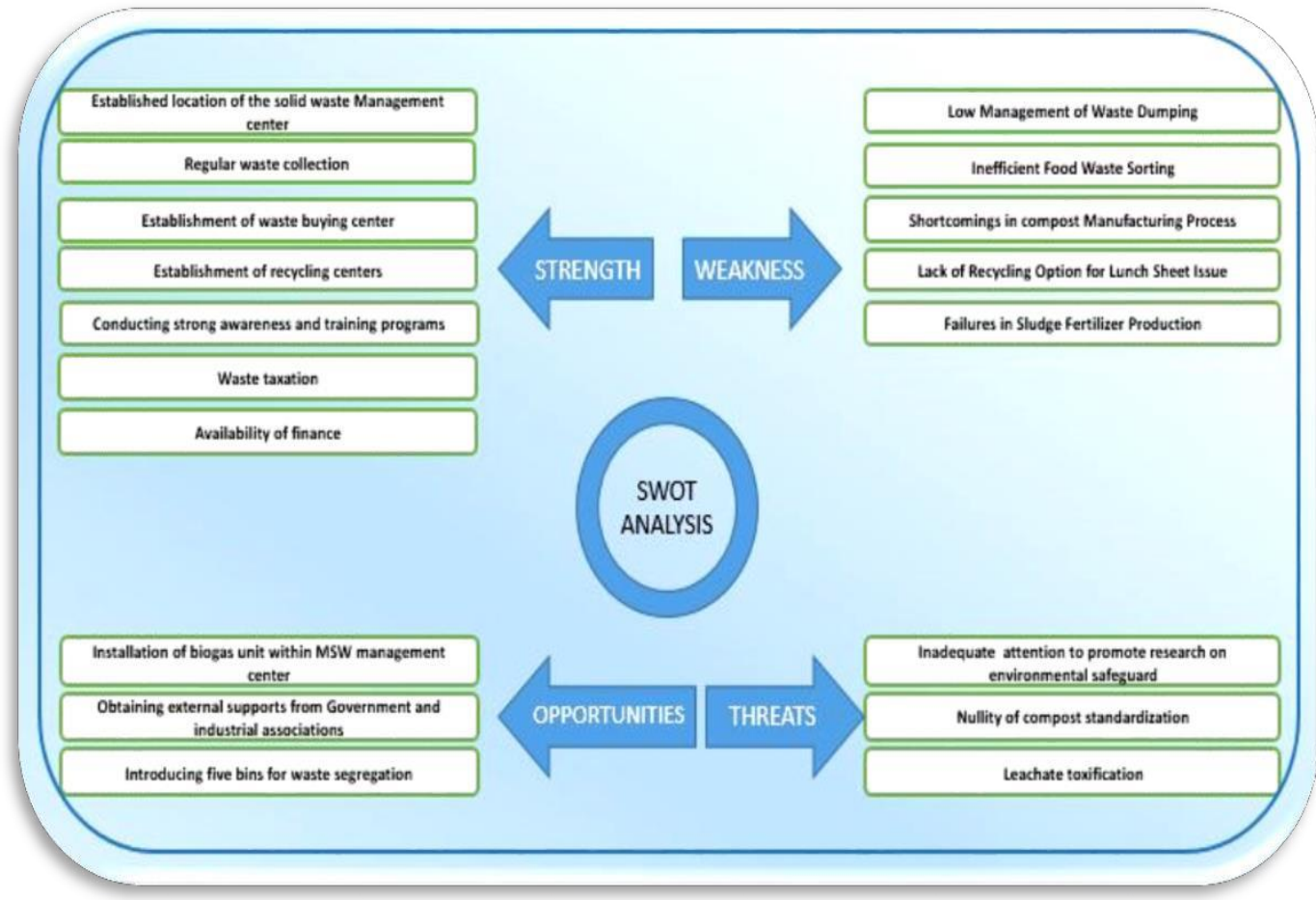

Figure 2. Flow Diagram is describing strength, weakness, opportunity and threats of solid waste dumping in the study area. 
by means of the intention whose notions explained at this time can be used to reinforce and direct this rising discipline[10].

\section{METHODOLOGY}

The process of Analytic hierarchy data driven decision support system is classified in Figure 3 to Figure 5 with the help of Simon's Model, where data has been gathered, processed and analyzed for the suitability indexes and after that finalized through efficiently methods of RS and GIS.

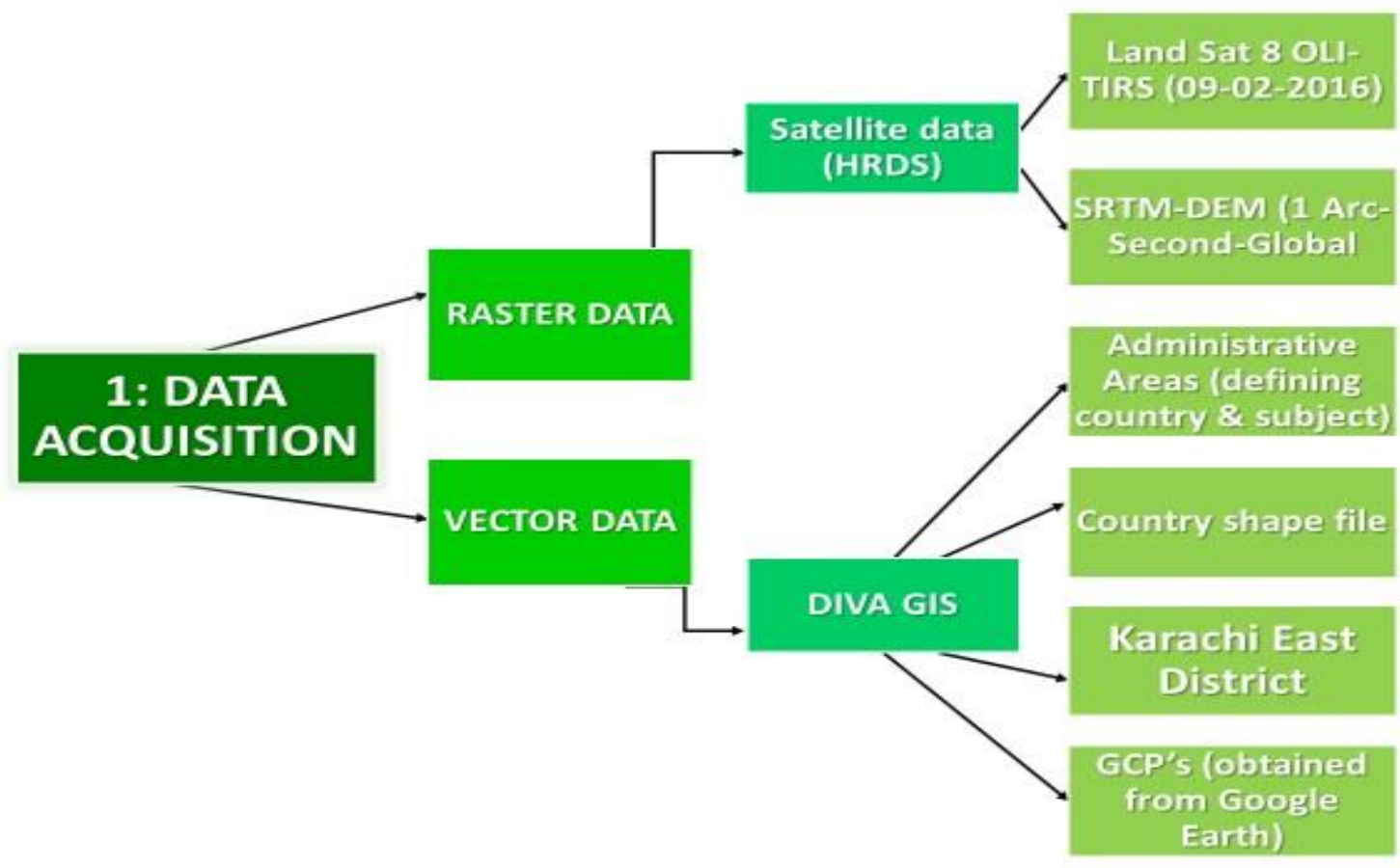

Figure 3. Flow Chart showing data acquisition.

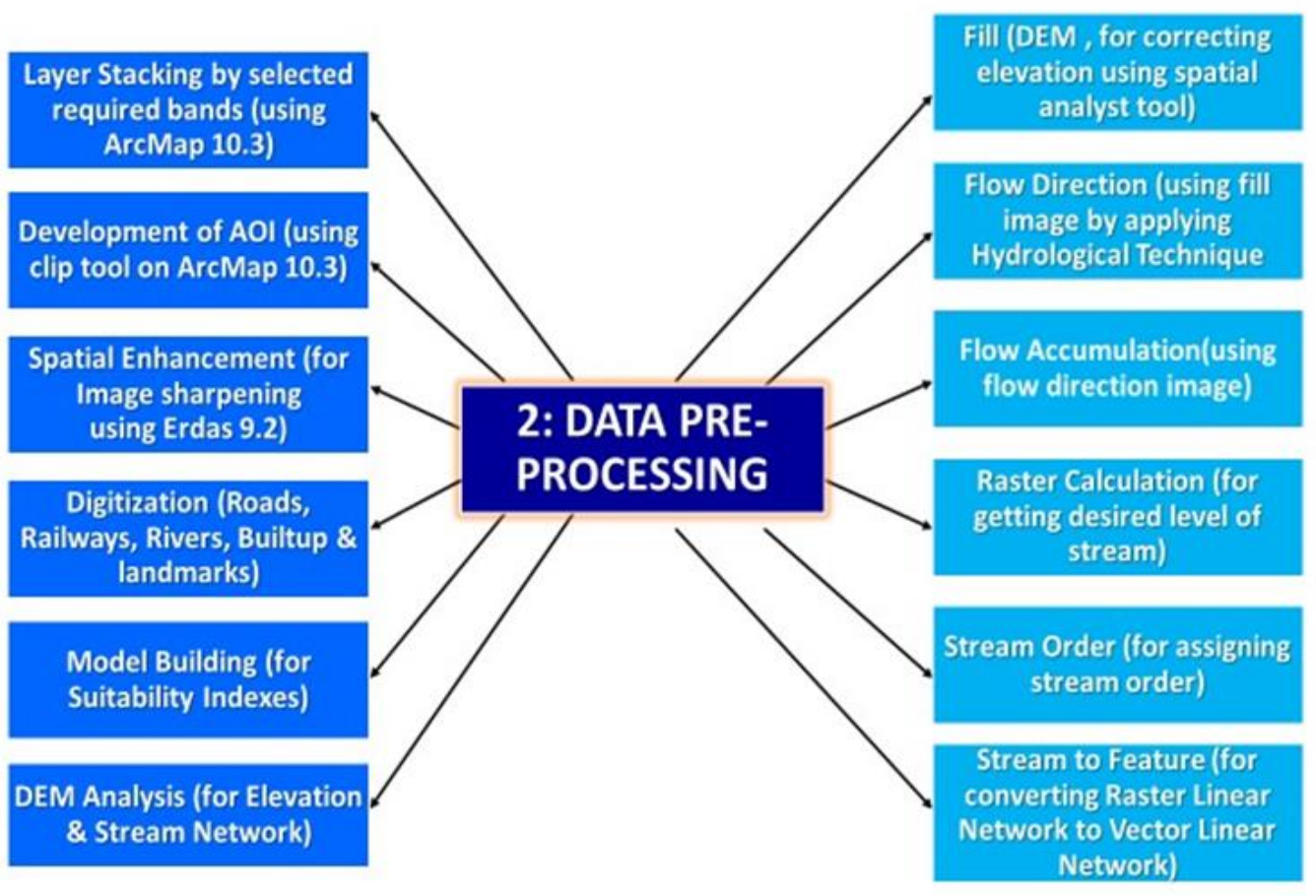

Figure 4. Flow Chart showing data pre - processing. 


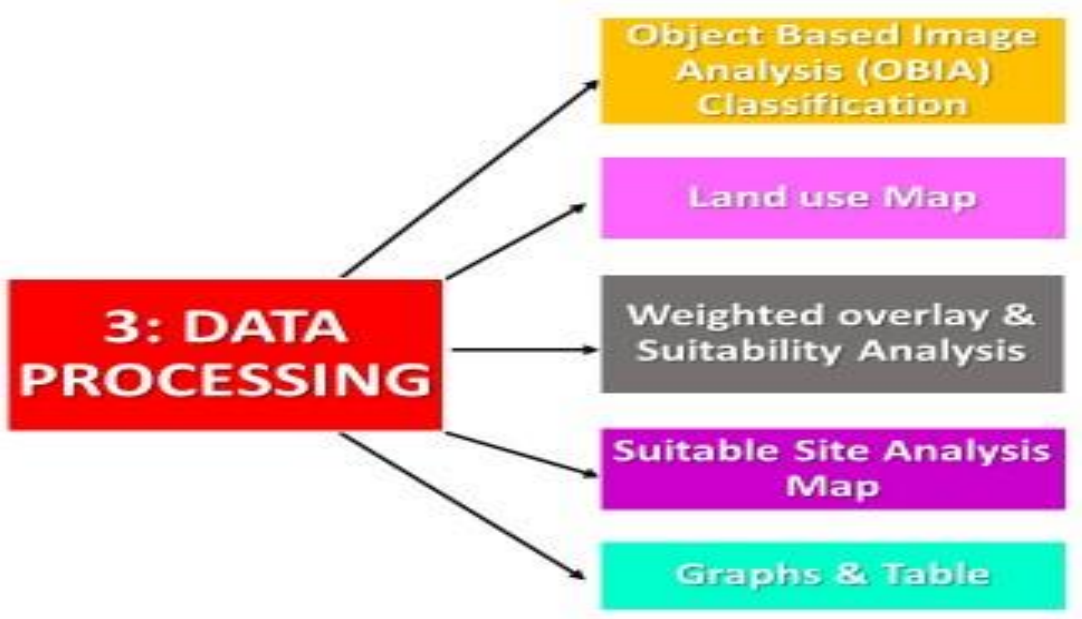

Figure 5. Flow Chart showing data processing.

\section{RESULTS AND DISCUSSIONS}

Communication driven decision support system used to choose the study area that improved decision making capabilities throughout the work done. Similarly, model driven support system manipulated the data to produce analytical results. Although Karachi East District does not have uneven (hilly) surface which contains low elevation level therefore few water bodies have came out in results given in Figure 6. Simultaneously, area is totally filled with land use features which have resulted in Figure 7.

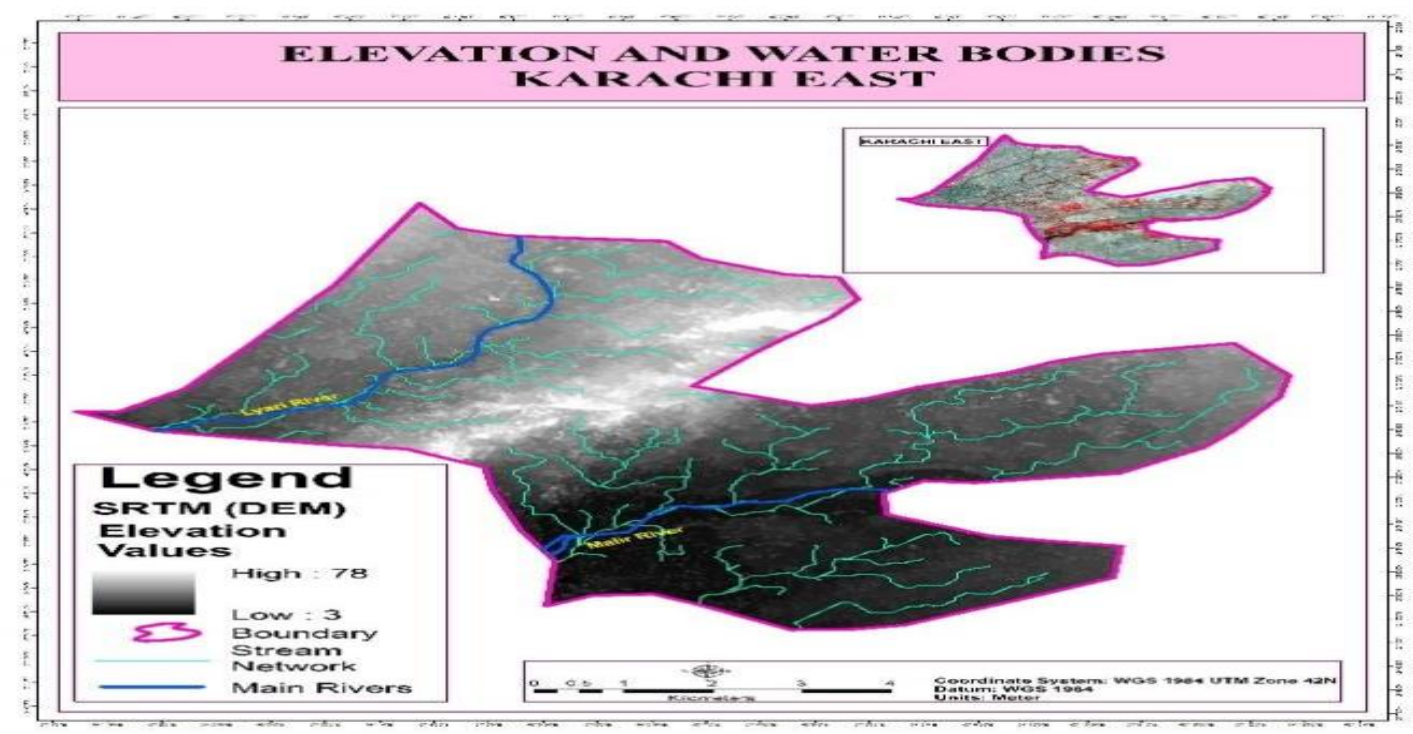

Figure 6. Elevation and water bodies lie in the Karachi East. 


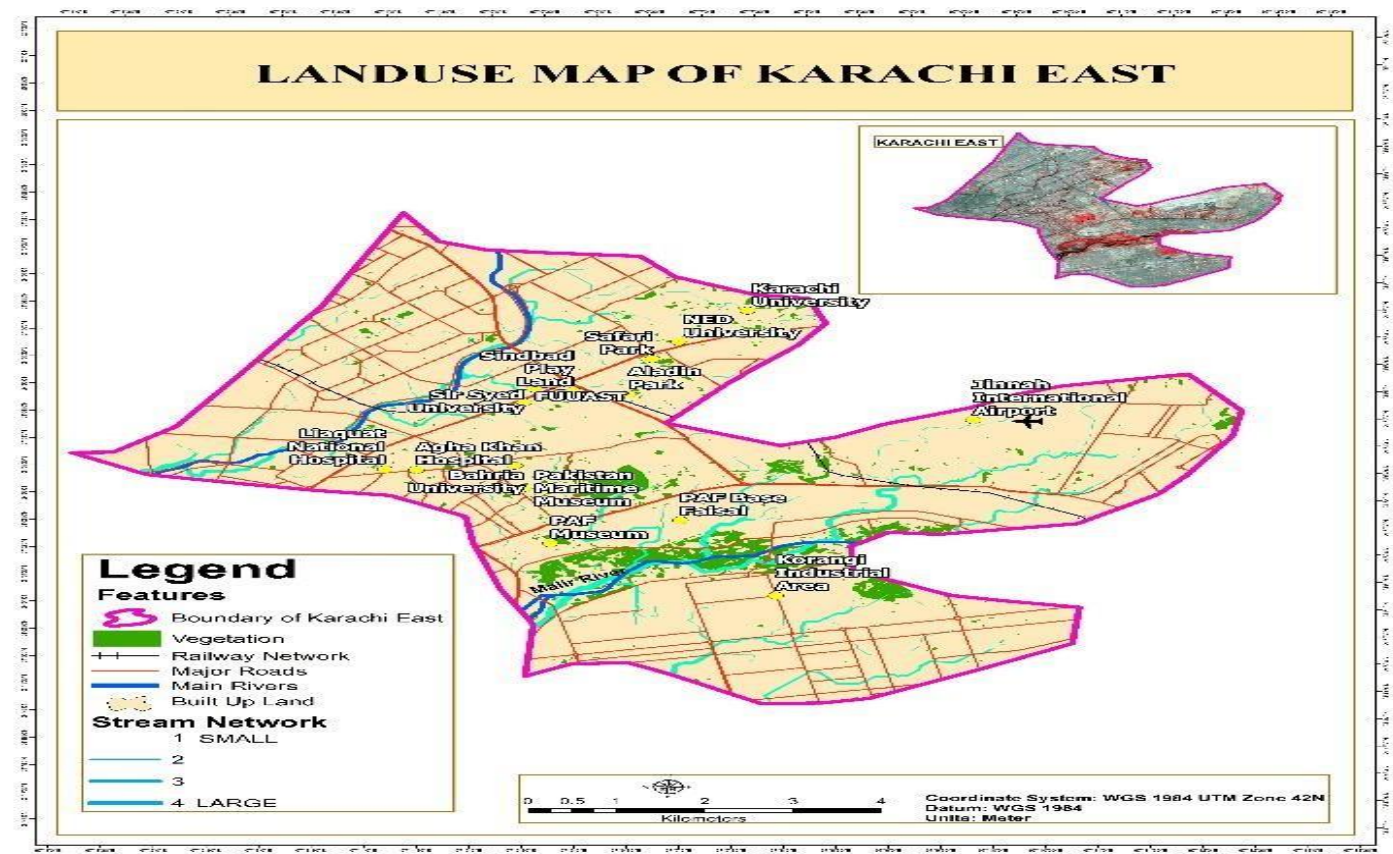

Figure 7. Land Use Map of Study Area.

Karachi city has 18 towns with 11 Dumping sites as shown in Table 1. But the identified dumping sites on the basis of origin are Jam Chakro, Gond Pass, Saba Cinema (North Karachi), Korangi 5, Lalabad (Landhi), Korangi 3.5 (Ibrahim Haidry Police Station) and Korangi 1.5 by 100 quarters. While main wastage dump in Gond Pass (1600 tons/day) and Jam Chakro (1200 tons/day) that means it represent approximately $45 \%$ of the total and there is only one dumping site which is not located on its best location for the whole district as shown in Figure 8. Moreover, the Sindh Solid Waste Management Board (SSWMB) has taken over the land of Karachi Development Authority (KDA) adjacent to Race Course near Safoora Chowrangi for the construction of a Garbage Transfer Station (GTS). However, building the GTS in District East is likely to prove hazardous for the city [11]. Additionally, researches describe that more landfill sites should be placed in urban region but far from populated areas rather than rural areas due to bulky amount of solid waste found in urban sites.

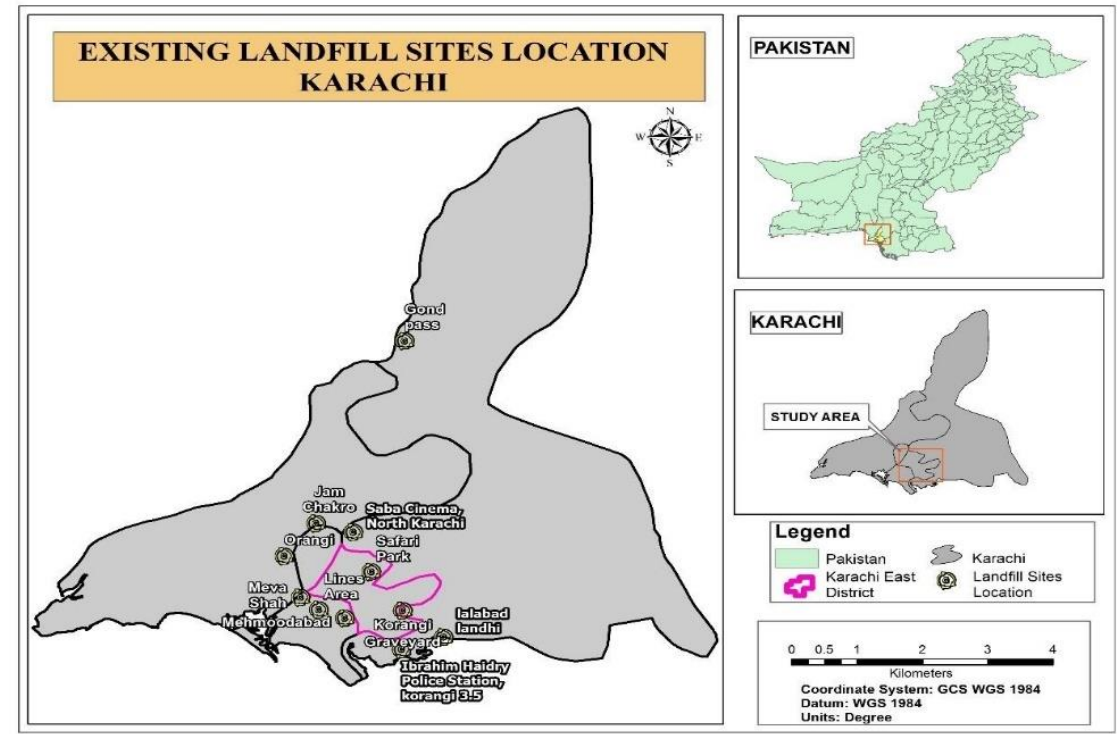

Figure 8. Map showing location of existing landfill sites in Karachi. 
Table 1. Locations of Landfill Sites in Karachi.

\begin{tabular}{|r|l|l|l|}
\hline S.No & \multicolumn{1}{|c|}{ Name of Site } & \multicolumn{2}{|c|}{ Coordinates } \\
\hline 1 & Jam Chakro & $\mathrm{N}=25^{\circ} 01.675^{\prime}$ & $\mathrm{E}=67^{\circ} 01.61^{\prime}$ \\
\hline 2 & Deh Gond Pass & $\mathrm{N}=25^{\circ} 00.634^{\prime}$ & $\mathrm{E}=66^{\circ} 55.263$ \\
\hline 3 & Mehmoodabad & $\mathrm{N}=24^{\circ} 50.906^{\prime}$ & $\mathrm{E}=67^{\circ} 04.212^{\prime}$ \\
\hline 4 & Safari Park & $\mathrm{N}=24^{\circ} 55.241^{\prime}$ & $\mathrm{E}=67^{\circ} 06.391^{\prime}$ \\
\hline 5 & Lines Area & $\mathrm{N}=24^{\circ} 51.903^{\prime}$ & $\mathrm{E}=67^{\circ} 02.292^{\prime}$ \\
\hline 6 & Orangi & $\mathrm{N}=24^{\circ} 56.210^{\prime}$ & $\mathrm{E}=67^{\circ} 00.379^{\prime}$ \\
\hline 7 & Meva Shah & $\mathrm{N}=24^{\circ} 53.332^{\prime}$ & $\mathrm{E}=67^{\circ} 00.338^{\prime}$ \\
\hline 8 & Korangi Graveyard & $\mathrm{N}=24^{\circ} 51.527^{\prime}$ & $\mathrm{E}=67^{\circ} 11.206^{\prime}$ \\
\hline 9 & Saba Cinema, North Karachi & $\mathrm{N}=24^{\circ} 59.250^{\prime}$ & $\mathrm{E}=67^{\circ} 5.169^{\prime}$ \\
\hline 10 & lalabad landhi & $\mathrm{N}=24^{\circ} 49.385^{\prime}$ & $\mathrm{E}=67^{\circ} 12.485^{\prime}$ \\
\hline 11 & Ibrahim Haidry Police Station & $\mathrm{N}=24^{\circ} 48.238^{\prime}$ & $\mathrm{E}=67^{\circ} 9.105^{\prime}$ \\
\hline
\end{tabular}

For getting better multi criteria decision making results which reduces outlays and speed turn-around on the next land-use/land-cover, vegetation or impermeable surface mapping project, Object-Based Image Analysis (OBIA) was performed initially on E-cognition Developer which is advanced method of image classification shown in Figure 9. Multi-scale segmentation has frequently been associated with theory of hierarchy [12].

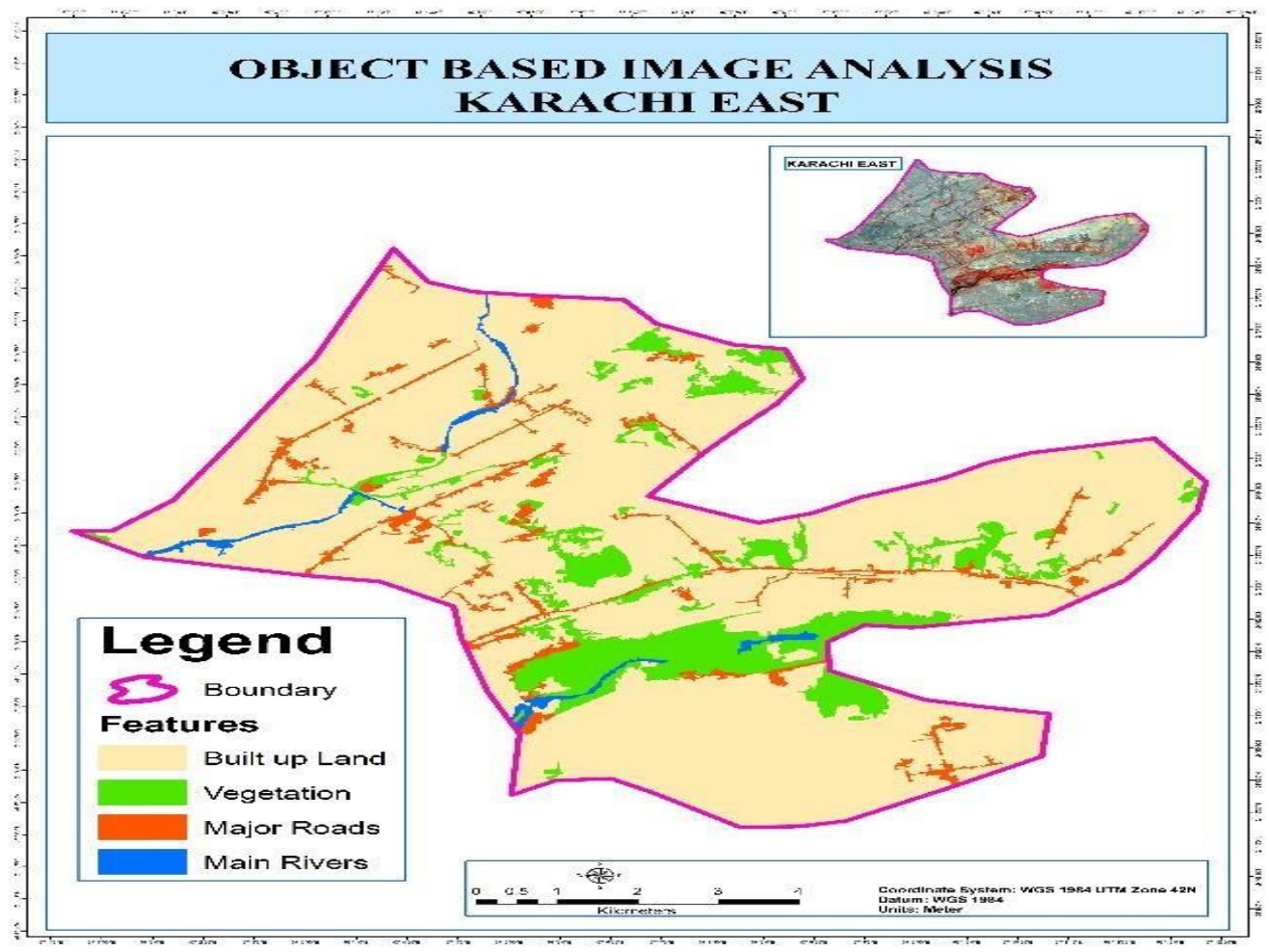

Figure 9. Map showing OBIA classification.

Figure 9 depicts the OBIA classification besides above technique, weighted overlay and suitability analysis is carried out on ArcGIS 10.3 software with the help of distinct aspects and creation of models in model builder used for selecting suitable land disposal site (Model: I, II \& III) as shown in fig. 10, 11 and 12. The problem over here is to make a suitability raster for the area of solid waste dumping site. These equations $1,2 \& 3$ define the suitability to be the total of weight criteria multiplied with the product of restrictions. 
$S=\sum_{i=1}^{n} w_{i} C_{i} \prod_{j=1}^{m} r_{j^{----------~} \rightarrow 1}$

Where

$-\mathrm{S}=$ Suitability for a waste disposal site

$-W_{i}=$ Weight for Criteria $i C_{i}$

$-C_{i}=$ Criteria for suitability

$-r i=$ Restriction

\section{Restriction Model \\ $S=\sum_{i=1}^{n} w_{i} C_{i} \prod_{j=1}^{m} r_{j}$

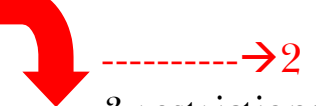 \\ 3 restrictions}

$S=\sum_{i=1}^{n} \mathrm{w}_{\mathrm{i}} \mathrm{C}_{\mathrm{i}}\left(\mathrm{r}_{\text {rivers }} * \mathrm{r}_{\text {roads }} * \mathrm{r}_{\text {landmarks }}\right)------>3$

Where,

$-\mathbf{r}_{\text {rivers }}=$ Restriction related to river location

$-\mathbf{r}_{\text {roads }}=$ Restriction related to roads location

$-\mathbf{r}_{\text {landmarks }}=$ Restriction related to parks and reserves location

Restriction in Buffer is shown in Table 2. Most restrictions included a Minimum and Maximum Buffer Zone with Analysis Buffer.

Table 2. Restriction Buffer.

\begin{tabular}{|l|c|c|c|}
\hline Restriction Source & $\begin{array}{c}\text { Minimum Buffer } \\
\text { Distance (m) }\end{array}$ & $\begin{array}{c}\text { Maximum } \\
\text { Buffer Distance } \\
(\mathbf{m})\end{array}$ & $\begin{array}{c}\text { Analysis Buffer } \\
\text { Distance (m) }\end{array}$ \\
\hline Rivers & 30 & 200 & 200 \\
\hline Roads & 50 & 300 & 300 \\
\hline Landmarks & 300 & 3000 & 1000 \\
\hline
\end{tabular}

Restriction in Raster are shown in Table 3.

Restrictions in raster exposed here through Boolean expression where restricted cell is shown with 0 and viable cell is represented with 1 to develop a waste disposal site.

Table 3. Restrictions in Raster.

\begin{tabular}{|c|c|c|c|}
\hline 0 & 1 & 1 & 0 \\
\hline 1 & 1 & 0 & 0 \\
\hline 1 & 1 & 1 & 0 \\
\hline 1 & 0 & 0 & 0 \\
\hline
\end{tabular}




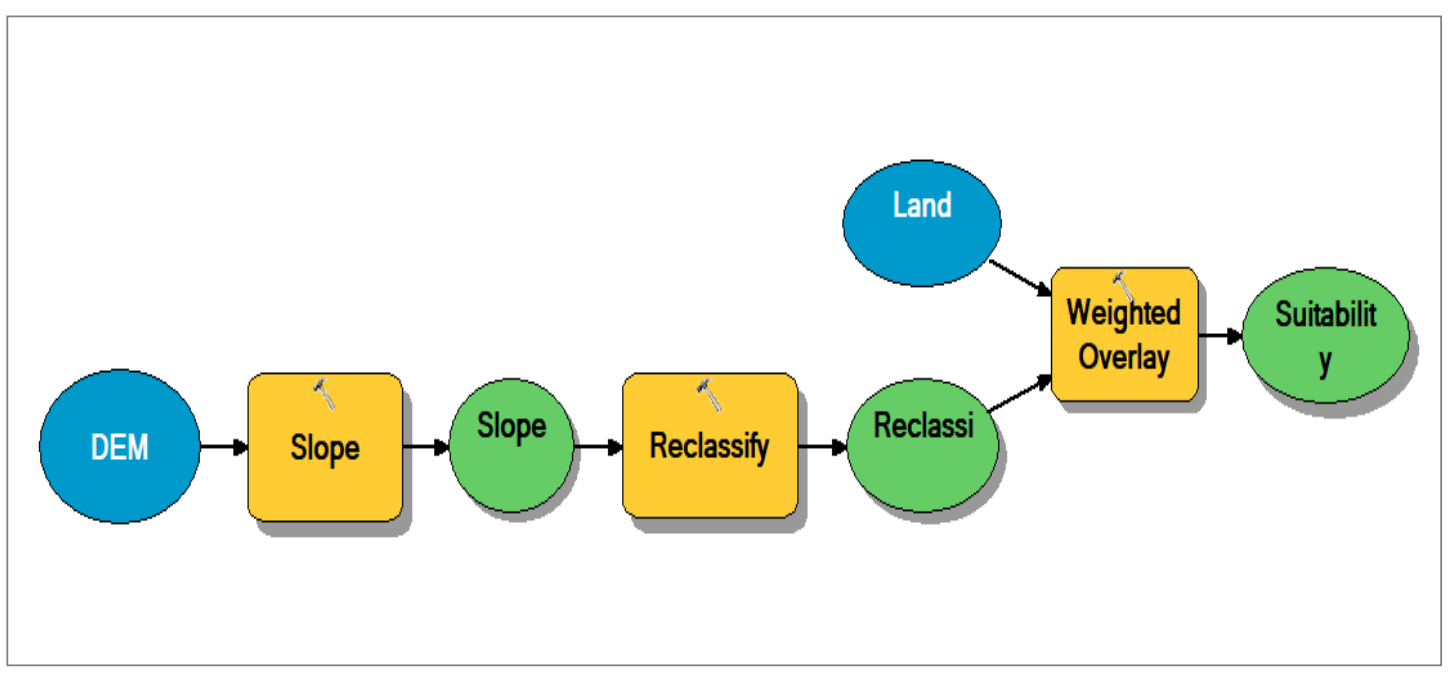

Figure 10. Model I Suitability Model.

$S=\sum_{i=1}^{n} w_{i} C_{i} \prod_{j=1}^{m} r_{j}$

$S=\sum_{i=0}^{n}\left(w_{s} C_{s} * w_{l u} C_{l u}\right) \prod_{j=1}^{m} r_{j}$

\section{Where:}

$-w_{s} \& C_{s}=$ Weight and criteria for slope

$-w_{l u} \& C_{l u}=$ Weight and criteria for land use

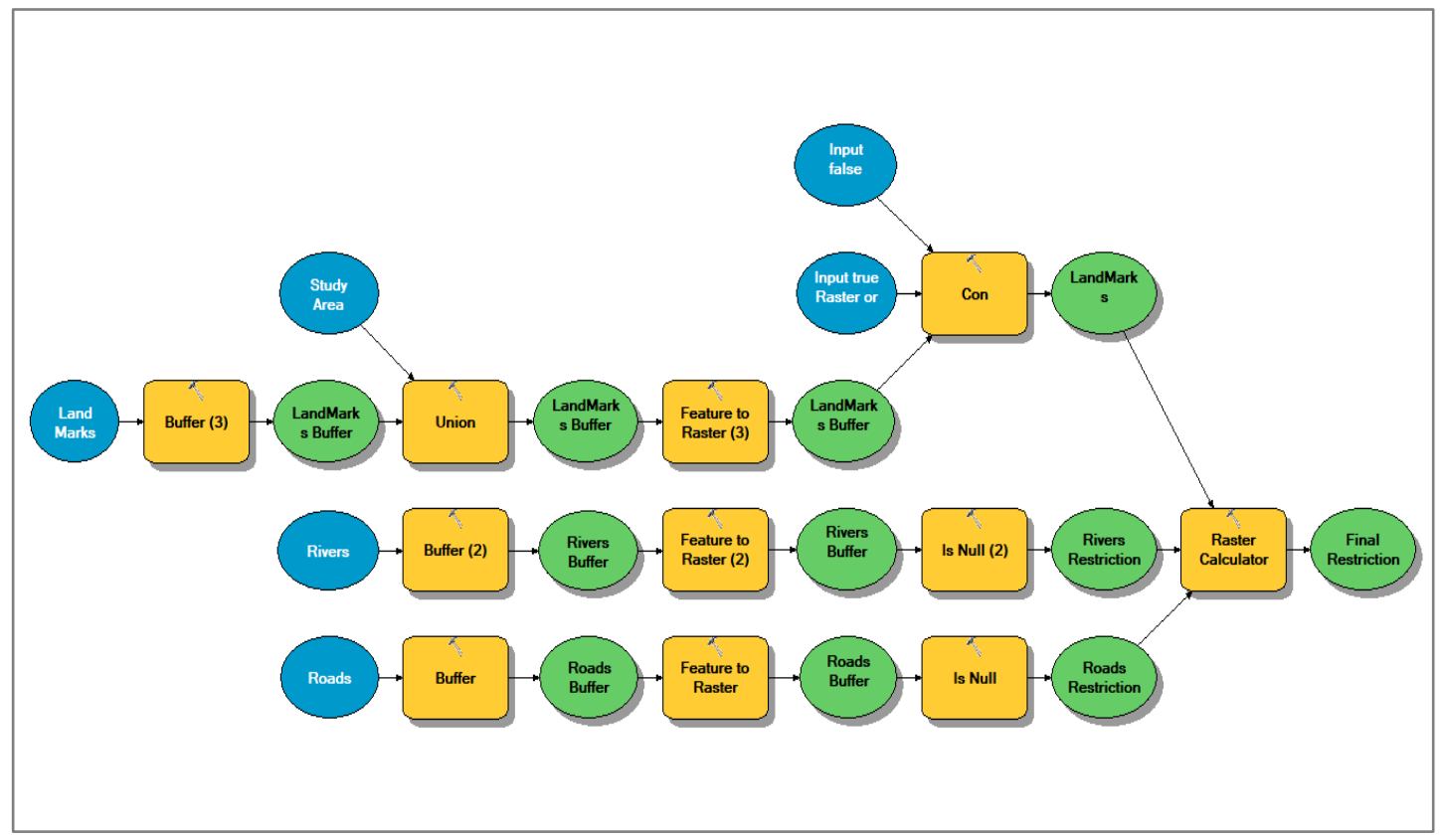

Figure 11. Model II: Weights and Evaluation Scale.

\section{Weights and Evaluation Scale}

- Weights

$$
\mathrm{S}=\sum_{i=1}^{n}\left(0.40 C_{s} * 0.60 C_{l u}\right) \prod_{j=1}^{m} r_{j}
$$

- Evaluation Scale

---1 ---5 step of 1 


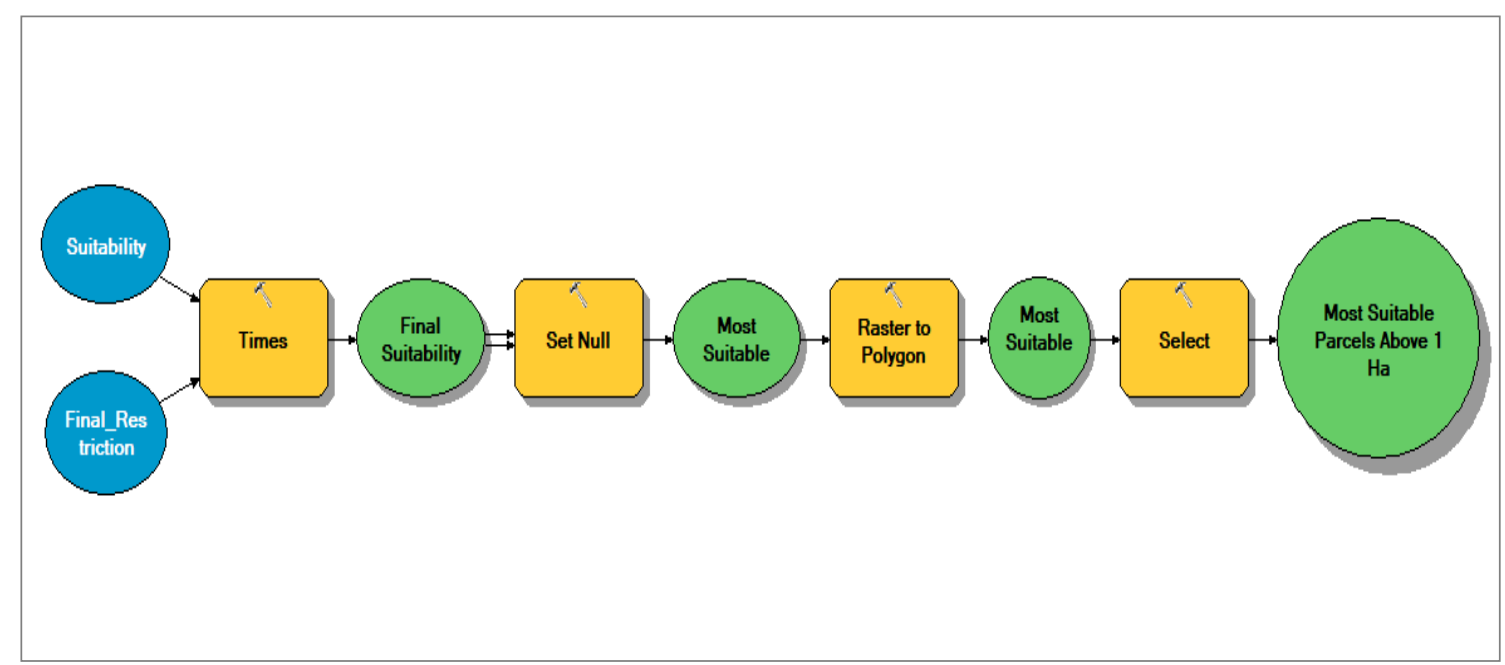

Figure 12. Model III: Parcel Selection Criteria 1.

For selecting best suitability value i.e. 3 in this analysis, parcel selection criteria have been applied whereas most suitable parcels are above than one hector $(10,000 \mathrm{~m} 2)$ in Karachi East's boundary (Model: III).

\subsection{Landmarks Buffer to Landmarks Raster Buffer with Restriction constants}

District East Karachi consists of many famous landmarks shown in Figure 13 (A). Solid waste dumping site should not be the surroundings of landmarks. For this purpose, a $1000 \mathrm{~m}$ buffer zone is applied from all landmarks. Landmarks buffer have been united with the boundary of study area for finding the extent in Figure 13 (B). Whereas Restriction constants -1 (high restriction) and 1 (low restriction) is applied in Raster Buffer zone to determine unacceptable areas for solid waste dumping in Figure $13(\mathrm{C})$.
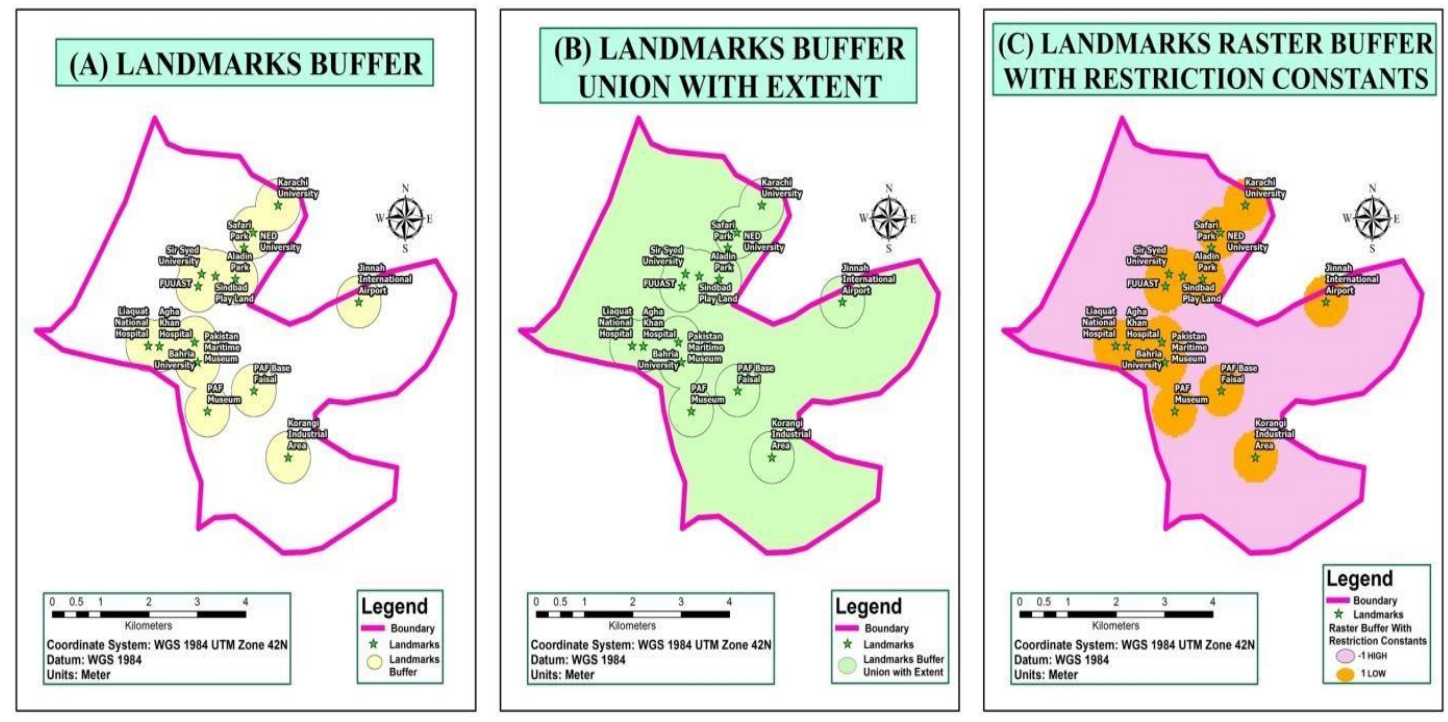

Figure 13. Maps of Suitability Indexes: (A) Landmarks Buffer (B) Landmarks Buffer union with extent (C) Landmarks Raster Buffer with Restriction Constants.

\subsection{Rivers B uffer to River Restriction}

The waste dumping areas should be away from rivers, lakes, or swamps where the underground water level is high. As the main rivers have an excessive discharge and immense downstream impact, therefore no landfill should be placed in the 
floodplains of main rivers [13]. Consequently, a buffer of $200 \mathrm{~m}$ is applied in Figure 14 (D). For getting desire river restrictions output a layer of vector river buffer converted into raster river buffer in Figure 14 (E) because Boolean Expression can be applied on Raster Calculator using raster layer. Result of river restriction is shown in Figure $14(\mathrm{~F})$ with the value of 0 (high restriction) and 1 (low restriction).
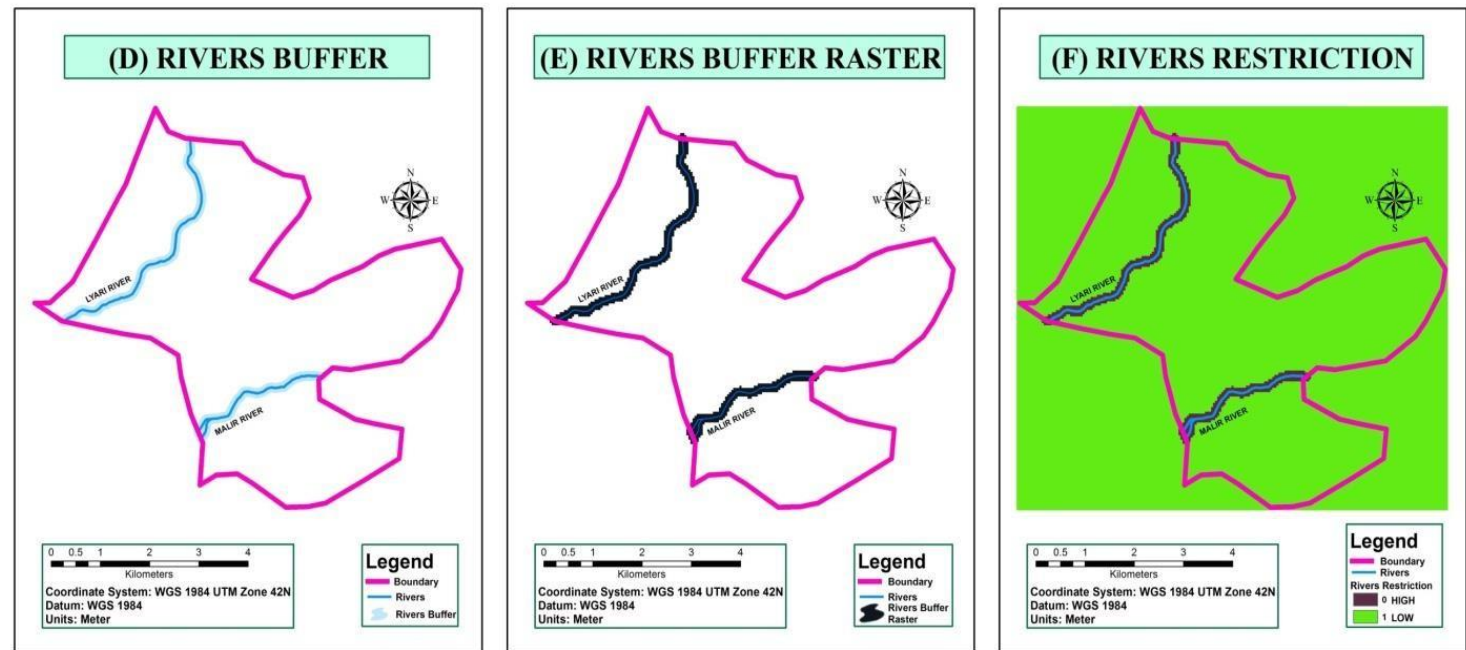

Figure 14. Maps of Suitability Indexes: (D) River Buffer (E) River Buffer Raster (F) River Restriction.

\subsection{Roads Distance to Final Raster Restrictions constants}

The District consists of main roads, secondary roads and pedestrian roads. The waste dumping sites should not be near to the road networks. Therefore, a $300 \mathrm{~m}$ buffer zone is applied to these networks shown in Figure 15(G) Raster Buffer is showing restriction constant where Boolean expression stated high restriction 0 and low restriction 1 for solid waste land disposal in Figure 15(H) Output of Final Raster restriction constants with rivers, roads and Landmarks also gave result with Boolean expression such as 0 (high restriction for solid waste dumping) and 1 (low restriction for solid waste dumping) in Figure 15(I).
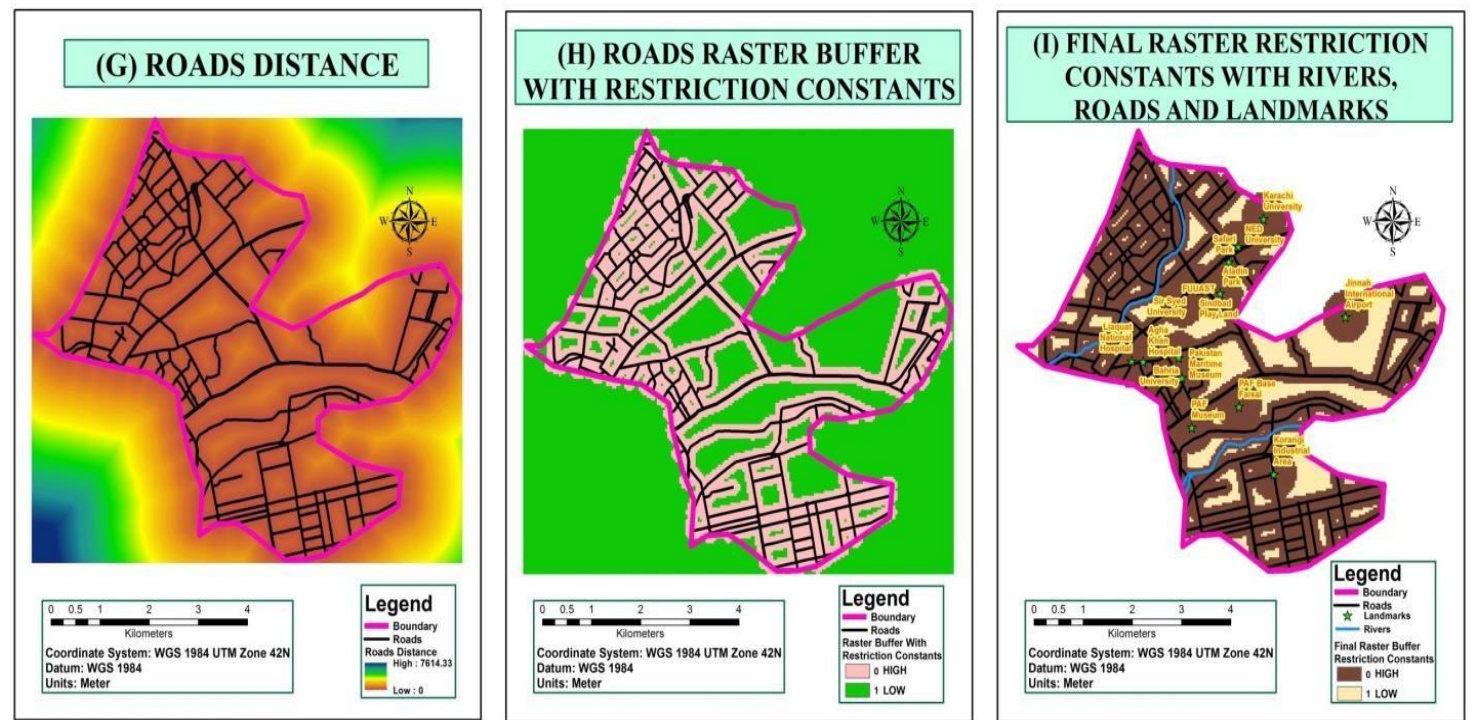

Figure 15. Maps of Suitability Indexes: (G) Roads Distance (H) Roads Raster Buffer with Restriction Constants (I) Final Restriction Constants with Rivers, Roads and Landmarks. 


\subsection{Suitability Ratio to Most Suitable Parcel}

Most of the land disposal site analyzed at a constant given distance from rivers and roads and far from populated areas shown in Fig 16(J). Thus, additional evaluation was done in ArcGIS environment to get most suitable parcels at high suitable ratio in Fig 16(K). Finally, the suitability indexes excluded small parcels that were less than 1 hectare and highlighted the areas in circle (red) from the sites classified as high suitable for

solid waste dumping whereas with black box as shown in Fig 16(L) is most highly appropriate spot for solid waste dumping which is $200 \mathrm{~m}$ away from Malir River in the study area.
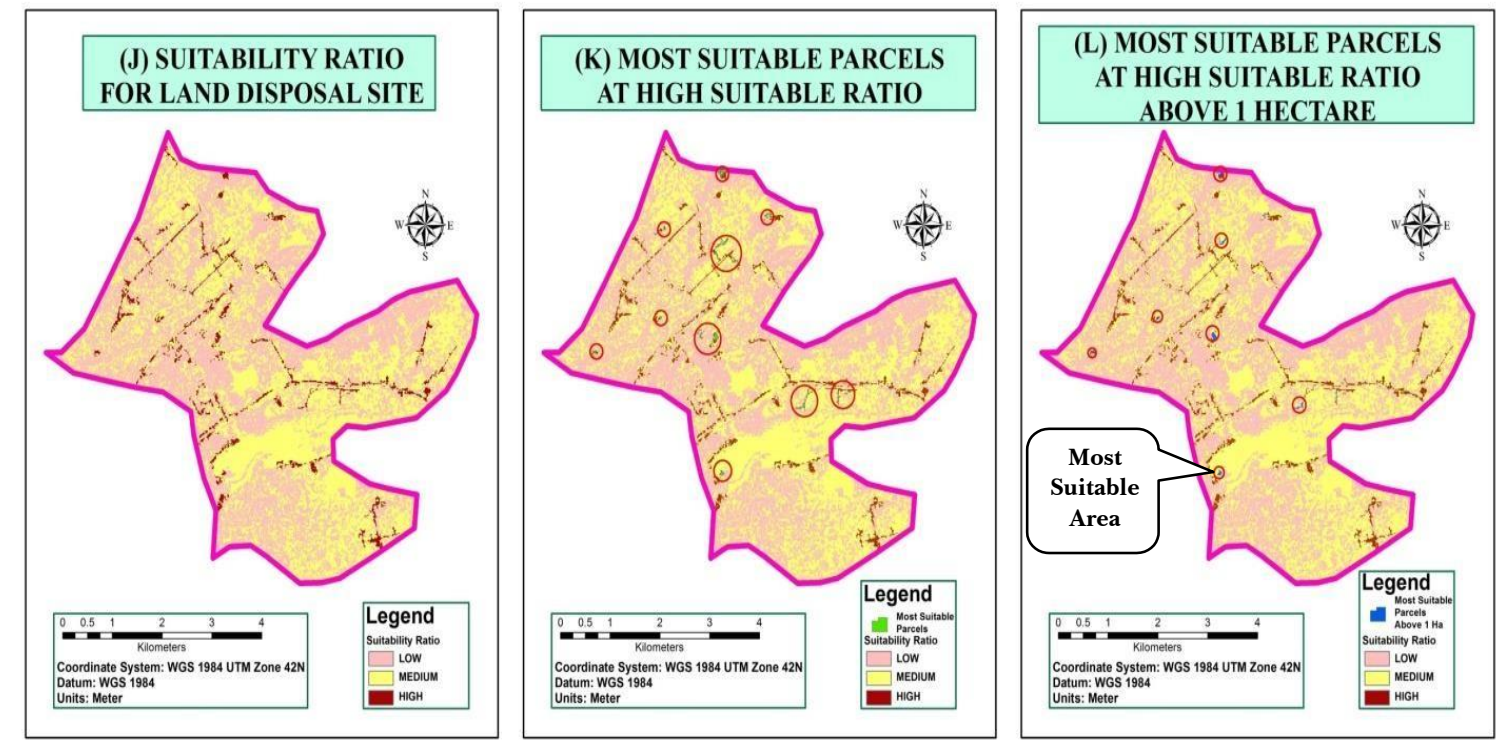

Figure 16. Maps of Suitability Indexes: (J) Suitability Ratio for Land Disposal Site (K) Most Suitable Parcels at High Suitable Ratio (L) Most Suitable Parcels at High Suitable Ratio above $1 \mathrm{Ha}$.

\section{CONCLUSION}

Spatial Decision Support System (SDSS) helps in decision making and Analytic Hierarchy processes that are suitable for organizing complex decisions resulting in appropriate site selection for solid wastes which are believed to be far away from urban population. In this study, through the technique of Analytic Hierarchy Process (AHP) and Multi-Criteria Decision Making (MCDM), suitable alternative site for dumping solid waste has been selected on the basis of different factors performed on Arc Map 10.3, Erdas Imagine, e-Cognition developer for fulfillment of decision maker's expectations. After performing different investigations on the suitability indexes, the analyzed area most suitable for solid waste dumping came out to be $200 \mathrm{~m}$ away from Malir River.

\section{REFERENCES}

[1] Haq Nawaz Abbasi, Xiwu Lu and Guangyu Zhao "An Overview of Karachi Solid Waste Disposal Sites and Environs" Journal of Scientific Research \& Reports 6(4); Article no.JSRR.2015.155 ISSN: 2320-022 pp 294-303, (2015)

[2] K. Anitha, S.Janani, A.Hemanthra, R Bhavani, L. "Iyappan Optimum route analysis to drinking water pipeline for vellore Taluk Using GIS and Remote Sensing" International Conference on Engineering Materials and Processes (ICEMAP2017, (2017) March. 
[3] Genemo Berisa (M.Sc. GIS ) and Yohanis Birhanu (M.Sc. Environmental Science) "Municipal Solid Waste Disposal Site selection of Jigjiga Town Using GIS and Remote Sensing Techniques, Ethopia” International Journal of Scientific and Research Publications, 1 ISSN 2250-3153 Volume 5, Issue 4, April (2015).

[4] Thomas, Lang, Stefan, Hay, Geoffrey “Object-based image analysis: spatial concepts for knowledge-driven remote sensing applications: Springer Science \& Business Media” Springer-Verlag Berlin Heidelberg, Edition Number 1, 2008, Book ISBN 978-3-540-77058-9, DOI 10.1007/978-3-540-77058-9.

[5] Katja Buhrkal, Allan Larsen, Stefan Ropke "The waste collection vehicle routing problem with time windows in a city logistics context" The Seventh International Conference on City Logistics 39 pp 241 - 254 (2012)

[6] Asha Poorna C, Vinod P. G "Solid waste disposal site selection by data analysis using GIS and Remote sensing tools: A case study in Thiruvananthapuram corporation area" INTERNATIONAL JOURNAL OF GEOMATICS AND GEOSCIENCES, Volume 6 Issue 4, pp 1734- 1747, (2016)

[7] Chabuk A , Al-Ansari N , Hussain HM , Knutsson S , Pusch R "Landfill site selection using geographic information system and analytical hierarchy process: A case study Al-Hillah Qadhaa, Babylon, Iraq" OSAGE Journal, volume 34(5), pp 42737, May ,(2016)

[8] Ali Jalil Chabuk1, Nadhir Al-Ansari1, Hussain Musa Hussain, Sven Knutsson1, Roland Pusch "Landfill Sites Selection Using Analytical Hierarchy Process and Ratio Scale Weighting: Case Study of Al-Mahawil, Babylon, Iraq” Engineering, volume 9, pp 123-141, February 16, (2017).

[9] Tirusew Ayisheshim Ebistu 1 and Amare Sewnet Minale " Solid waste dumping site suitability analysis using geographic information system (GIS) and remote sensing for Bahir Dar Town, North Western Ethiopia” African Journal of Environmental Science and Technology Vol, 7(11), pp 976-989, November (2013)

[10] G.J. Hay, G. Castilla "Object-Based Image Analysis, Strengths, Weaknesses, opportunities and Treats (SWOT)" The International Archives of the Photogrammetry, Remote Sensing and Spatial Information Sciences, (2006)

[11] Oonib Azam "New garbage transfer station likely to be hazardous for Karachi" Express Tribune, March 20th, (2017)

[12] Jamshidi-Zanjani, A. \& Rezaei, M. Environ "Landfill site selection using combination of fuzzy logic and multi-attribute decisionmaking approach" Springer-Verlag GmbH Germany (2017) 16 June (2017)

[13] Cengiz Kahraman, Mehdi Keshavarz-Ghorabaee, Edmundas Kazimieras Zavadskas and Sezi Çevik "Intuitionistic fuzzy EDAS method: an application to solid waste disposal site selection" Journal of Environmental Engineering and Landscape Management, Volume 25(01) pp 1-12, March (2017). 


\section{AUTHORS}

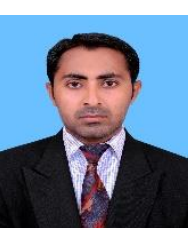

\section{Sikandar Ali}

sayed.sikandar24@gmail.com

MS (RS \& GIS) From Department of Geography University of Karachi Pakistan, Currently working as lecturer at Faculty of Engineering, Science \& Technology Indus University Pakistan

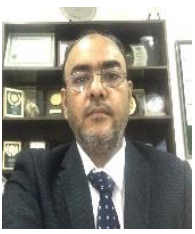

\section{Prof. Dr. Engr. Sayed Hyder Abbas Musvi}

sayed.sikandar24@gmail.com

Senior Member of IEEE

Dean at Faculty of Engineering, Science \& Technology Indus University, Karachi, Pakistan

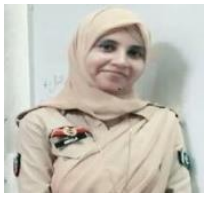

\section{Abeela Tameez}

picesfrienda18@gmail.com

MS (RS \& GIS) Student Department of Geography University of Karachi, Pakistan

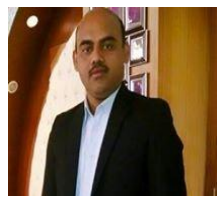

\section{Masood Alam}

masood.78@hotmail.com

MS (RS \& GIS) Student Department of Geography University of Karachi, Pakistan

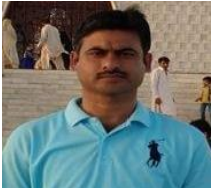

\section{Asim Nawaz}

asimpmd@gmail.com

MS (RS \& GIS) Student Department of Geography University of Karachi 
